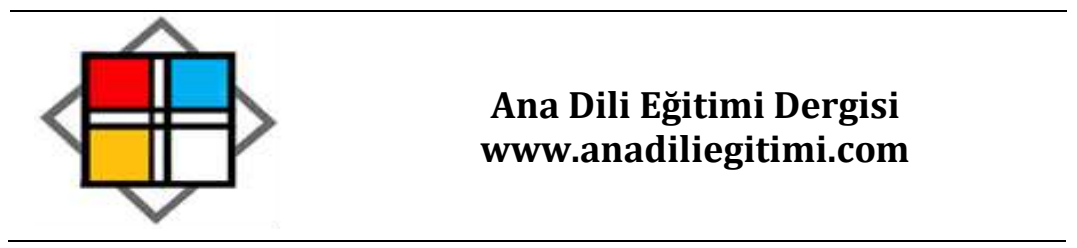

\title{
İlkokul Dördüncü Sınıf Öğrencilerinin Kitap Okuma Motivasyonlarının İncelenmesi
}

\author{
Mehmet KATRANCI
}

Gönderilme: 12.03.2015 / Düzeltme: 08.04.2015 / Kabul Edilme: 08.04.2015

Öz

Bu çalışmanın amacı, ilkokul dördüncü sınıf öğrencilerinin kitap okuma motivasyonu düzeylerinin belirlenmesidir. Tarama modelinde gerçekleştirilen araştırmanın örneklemi Kırıkkale il merkezinde bulunan 32 resmî ilkokulun dördüncü sınıflarında öğrenim gören 422 kız ve 369 erkek olmak üzere toplam 791 öğrenciden oluşmaktadır. Veriler kişisel bilgi formu ve Kitap Okuma Motivasyonu Ölçeğ ile toplanmıştır. Verilerin analizinde bağımsız gruplar için t-Testi, tek faktörlü ANOVA ve basit doğrusal regresyon analizi kullanılmıştır. Araştırma sonucunda; ilkokul dördüncü sınıf öğrencilerin kitap okumaya yönelik motivasyonlarının orta düzeyde olduğu, kız öğrencilerin kitap okuma motivasyonlarının erkek öğrencilere göre daha yüksek olduğu ve anne-baba öğrenim düzeyinin kitap okuma motivasyonu üzerinde etkili olduğu belirlenmiştir. Ayrıca kendine ait kitaplığa sahip olma durumunun kitap okuma motivasyonunu olumlu yönde etkilediği ve kitap okuma motivasyonunun Türkçe dersi akademik başarısının \%9'unu açıkladığı tespit edilmiştir. Araştırmadan elde edilen bulgular daha önce yapılan benzer çalışmaların sonuçlarıyla karşılaştırılarak tartışılmış ve bulgulara yönelik önerilerde bulunulmuştur.

Anahtar kelimeler: Kitap okua motivasyonu, akademik başarı, dördüncü sınıf öğrencileri.

\section{Investigation of the Book Reading Motivation of Elementary School Fourth Graders}

\begin{abstract}
The purpose of the present study is to determine the book reading motivation level of elementary school fourth graders. The sampling of the study conducted in survey model consists of totally 791 elementary school fourth graders from 32 different elementary schools in the city of Kırıkkale. Of the participants, 422 are girls and 369 are boys. The data of the study were collected with a personal information form and the Book Reading Motivation Scale. In the analysis of the data, $t$ test, one-way ANOVA and simple linear regression analysis were used. At the end of the study, it was concluded that the students' reading motivation level is medium in general, the girls' book reading motivation level is higher than that of the boys and the father and the mother's education levels have a significant effect on the students' reading motivation. Moreover, the student's having his/her library positively affects book reading motivation and book reading motivation accounts for $9 \%$ of the academic achievement in Turkish Language course. The results of the present study were discussed by means of comparison with the results reported by similar studies in literature and in light of the findings, some suggestions were made.
\end{abstract}

Keywords: Book reading motivation, academic achievement, forth grade student.

\footnotetext{
${ }^{*}$ Yrd. Doç. Dr., Kırıkkkale Üniversitesi, Eğitim Fakültesi, İlköğretim Bölümü. Kırıkkkale e-posta: mkatranci@gmail.com
} 


\section{Giriş}

Dünyayı anlayabilmek, yeniliklere uyum sağlayarak bilgiyi dönüştürebilmek için insanın okumaya ve anlamaya ihtiyacı vardır. Eğitimin temel gayesi insandaki bu ihtiyacı karşılayabilmek ve öğrenme becerilerinin gelişmesini sağlayabilmektir. Farklı amaçlar için farklı kitapları okuma ve anlayabilme; analiz-sentez becerilerinin gelişmesi, olaylara farklı açılardan bakabilme, yaşadığı toplumun ekonomik ve sosyal süreçlerine katılabilmeye imkân sağlamaktadır.

Kitap okuma davranışını etkileyen pek çok sebepten biri de motivasyondur. Kitap okuma, öğrencileri yapmak ile yapmamak arasında tercihe yönelten ve çaba gerektiren bir beceridir. Bu çaba, motivasyonu zorunlu kılmaktadır. Motivasyon, karmaşık bir kavramdır ve her öğrenci aynı etkinlikle güdülenemez. Gerçek bir öğrenmeden söz edilebilmesi için öğrencilerin, öğrenenler olarak kendileri, okulda başarılı olma yetileri, kendilerinin, öğretmenlerinin ve okullarının belirlediği öğrenim hedefleri hakkında olumlu tavırlara sahip olmaları gerekir (Graves ve diğ., 2011: 50). Motivasyon, organizmayı etkileyerek bir amaç için harekete geçiren, bu hareketi sürdürmesini sağlayan ve hareketin yönünü belirleyen dürtü, istek, ihtiyaç ya da hırstır (Slavin, 2013; Selçuk, 2007). Öğrencilerde motivasyonu etkileyen unsurlar Şekil 1'de sunulmuştur:

Şekil 1- Öğrenci Motivasyonunu Etkileyen Unsurlar (Tompkins, 2006: 236) uyarlanmıştır.

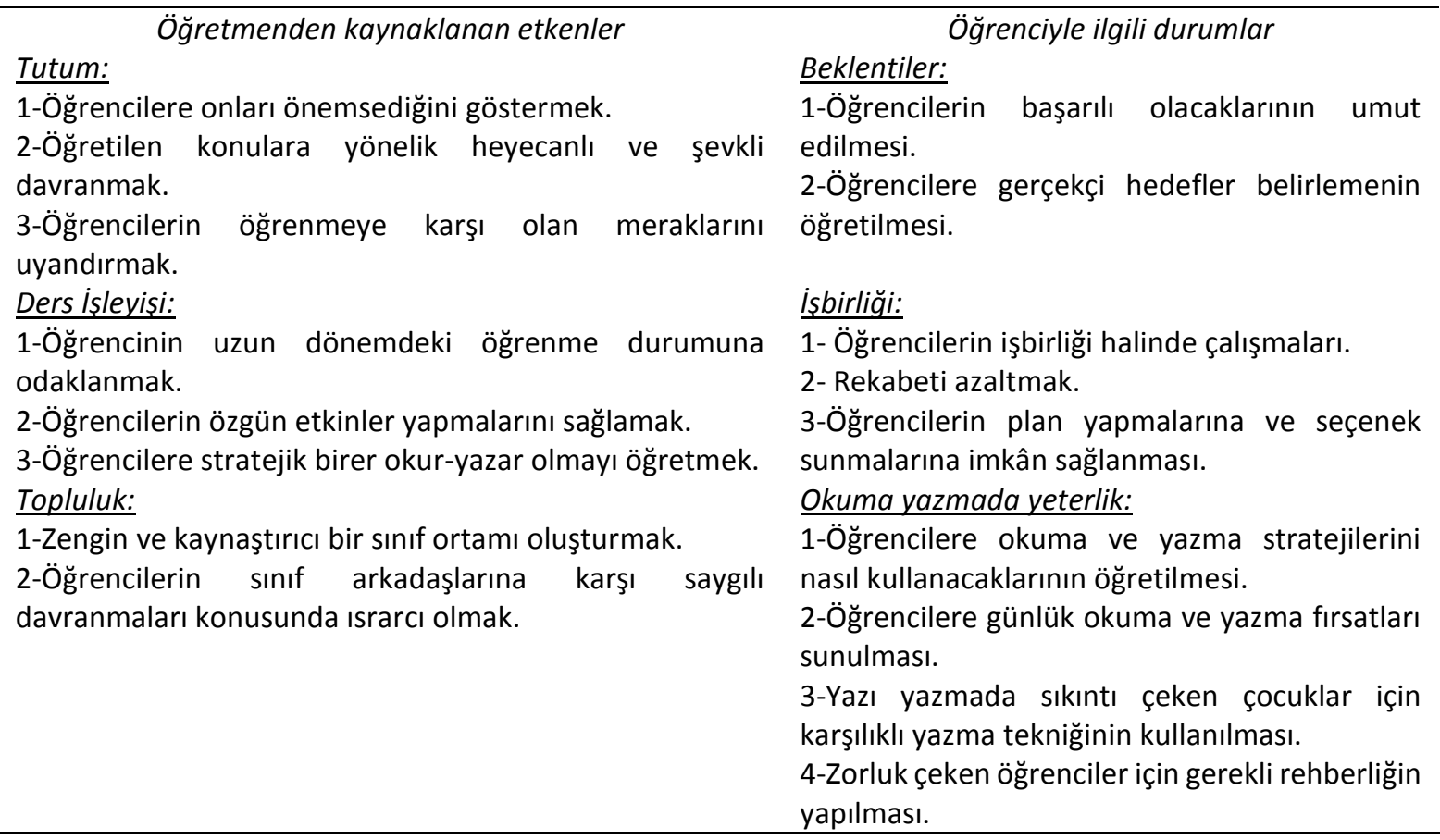

Kitap okuma motivasyonu; kitabı okumaya yönelik istek, merak, ilgi, tutum ve davranışın oluşabilmesi; kitap okumanın değerli bir eylem olarak görülmesi ve kitap okuma alışkanlığının devam edebilmesi için gerekli olan güçtür. Kitap okumaya yöneliş, kitap okumak için geçerli ve iyi bir sebep bulma, kitabı okumaya karar verme, bu kararı uygulamak için kütüphaneye/kitaplığa gitme, kitabı inceleme ve kitapla meşgul olmayı gerektirmektedir. Okuma tamamlandıktan sonra beklenen; kitapta 
anlatılanlar hakkında bir hüküm verilebilmesi, kişinin zihin dünyasının okunanlar yoluyla zenginleşebilmesidir.

Bazı öğrenciler okula yoğun bir öğrenme isteği ile gelmektedirler. Bu öğrenciler öğrenmeye ve ders çalışmaya karşı içsel bir motivasyona sahiptirler. Onlar için övgü ve tasvip etme yeterlidir. Diğer yandan öğrenmeye daha az ilgisi olan, hemen pes eden ve okulda olmaktan mutlu olmayan öğrenciler de vardır. Öğretmen bu öğrencilere ilgi göstermek ve onların öğrenmeye dair motivasyonlarını yüksek tutmak için belli teknikler kullanmak zorundadır. Yaşça küçük öğrenciler için dışsal ödüller kullanılabilir. Öğrencilerin -olumlu pekiştireçler sayesinde- derse katıımı ve derste geçirdikleri başarılı deneyimler arttıkça, okumaya karşı olumlu tutumları da artmaktadır. Kendi başarılarının farkına vardıkça da, içsel motivasyonları yükselmektedir (Carnine, Silbert, Kame'enui, Tarver ve Jungjohann, 2006: 30). Okuma motivasyonu; okuma konuları, süreçleri ve sonuçları ile ilgili olarak kişinin şahsi amaçlarını, değerlerini ve inançlarını kapsamaktadır. Motivasyonda öne çıkan özellik sürekli bir dönüşüm içinde ilgi, ihtiyaç ve çabadır. Çocuğu okumak için harekete geçirecek, eğitim yaşamı boyunca başarıyı tattıracak, onu okuma etkinliğiyle meşgul edecek gücün belirlenmesi önemlidir (Kuşdemir, 2014: 64). Okuduklarını rahatlıkla anlayabilen iyi okuyucuların okumaya yönelik motivasyonu yüksektir. Okuma motivasyonu yüksek olan birey, okuma etkinliğini sonuna kadar sürdürebilir (Guthrie, 2004). Okuma motivasyonu düşük olan öğrenciler, motivasyonu yüksek olan öğrencilerin aksine arkadaşlarıyla kitap paylaşmak, bir kitap üzerinde tartışmak, bir dergiyi takip etmek, kütüphaneye gitmek ya da kitap satın almaktan hoşlanmamaktadırlar. Bu öğrenciler kitabı okumaktansa, bir başkasından dinlemeyi ya da varsa filmini seyretmeyi tercih ederler (Beers, 1996; Akt: Baker, 2003: 99).

Okuma motivasyonu ilgi, güven ve adanmışlığı içermektedir. Zihnimiz öncelikle ilgilerimize yönelmektedir. Kitap okumaya yönelik motivasyon, bir kitabı sevmek, bir yazar hakkında heyecanlanmak veya yeni bir bilgi tarafından memnun edilmektir. Güven, bireyin kendisine olan inancıdır. Bu inanç tüm okul yaşamı boyunca diğer her türlü motive ediciden daha fazla başarı ile bağlantılıdır. Bu bağlantı okumada da etkilidir. Adanmışıı ise istek ile ilgilidir. Okumaya değer veren öğrenciler okumalarına çaba ve zaman harcamaları ve sebat etmeleri bağlamında adanmıştırlar. Adanmış öğrenciler, algıladıkları dünya ile ilgili bilgilerini genişleten bilgileri elde etmek için okuma yaparlar (Guthrie, 2011: 178). Araştırmalardan elde edilen sonuçlar ışığında öğrencilerini okumaya ve öğrenmeye güdülemek isteyen öğretmenlere yapılabilecek tavsiyeler şöyle sıralanabilir (Graves, Juel , Graves ve Dewitz, 2011: 74; Guthrie, 2011: 183-189):

Sınıfın endişe düzeyi düşük olmalıdır. Test etmeden ziyade öğrenmeye vurgu yapılmalıdır.

Öğrencilerin öğrenmekte oldukları şeyler hakkında tahminlerde bulunmaları sağlanarak merak canlı tutulmalıdır.

Öğrenciler öğrenme hedeflerinden haberdar edilmelidir. Neyi, ne için öğreneceğini bilmek motivasyonu artırır. 
Öğrencilere hak ettiklerinde özellikle övgü olmak üzere bilgilendirici geri bildirimde bulunulmalıdır.

Okumaya yönelik motivasyonun sağlanmasında en etkili yollardan biri öğrencilere tercih imkânı sunulmasıdır. Öğrenciler, ilgilerini çeken konuları okumaya daha fazla motivasyon gösterirler. Bu nedenle öğrencilerin ilgileri göz önünde bulundurulmalıdır. Ayrıca öğretmenler belirledikleri konulara yönelik olarak öğrencilerin ilgilerini artıracak etkinlikler tasarlayabilir.

Kitap okuma motivasyonunun önemi göz önünde bulundurularak bu araştırmada, ilkokul dördüncü sınıf öğrencilerinin kitap okuma motivasyonu düzeylerinin belirlenmesi amaçlanmıştır. Bu genel amaca yönelik olarak aşağıda belirtilen sorulara cevap aranmıştır.

- İlkokul dördüncü sınıf öğrencilerinin kitap okuma motivasyonları ne düzeydedir?

- 2-ilkokul dördüncü sınıf öğrencilerinin kitap okuma motivasyonları cinsiyete göre farklılık göstermekte midir?

- 3-ilkokul dördüncü sınıf öğrencilerinin kitap okuma motivasyonları anne eğitim düzeyine göre farklılık göstermekte midir?

- 4-ilkokul dördüncü sınıf öğrencilerinin kitap okuma motivasyonları baba eğitim düzeyine göre farklılık göstermekte midir?

- 5- İlkokul dördüncü sınıf öğrencilerinin kitap okuma motivasyonları kendine ait kitaplığa sahip olma durumuna göre farklılık göstermekte midir?

- 6- Illkokul dördüncü sınıf öğrencilerinin kitap okuma motivasyonları Türkçe dersi akademik başarısını yordamakta mıdır?

\section{Yöntem}

Araştırma, tarama modelinde gerçekleştirilmiştir. Tarama modeli, bir evren içinden seçilen bir örneklem üzerinde yapılan çalışmalar yoluyla evren genelindeki eğilim, tutum veya görüşlerin nicel veya sayısal olarak betimlenmesini sağlamaktadır (Creswell, 2014: 155).

\section{Evren ve Örneklem}

Araştırmanın evrenini Kırıkkale il merkezinde bulunan 32 resmî ilkokulun dördüncü sınıflarında öğrenim gören öğrenciler oluşturmaktadır. Örneklemin evreni temsil gücünün yüksek olması için belirtilen 32 ilkokulun her birinden seçkisiz yolla birer adet dördüncü sınıf örnekleme dâhil edilmiştir. Örneklem, 422 kız ve 369 erkek olmak üzere toplam 791 ilkokul dördüncü sınıf öğrencisinden oluşmaktadır.

\section{Veri Toplama Araçları}

Araştırmada iki adet veri toplama aracı kullanıımıştır. Veri toplama araçlarına yönelik bilgiler aşağıda sunulmuştur. 
Kişisel Bilgi Formu: Kişisel bilgi formuyla öğrencilerin cinsiyet, anne-baba öğrenim düzeyi, kendine ait kitaplığa sahip olma durumu ve Türkçe dersi akademik başarı puanı belirlenmeye çalışılmıştır.

Kitap Okuma Motivasyonu Ölçeği (KOMÖ): Araştırmada kullanılan KOMÖ, Katrancı (2015) tarafından ilkokul 4. sınıf ile ortaokul 5 ve 6 . sınıf olmak üzere toplam 1224 öğrencinin katılımıyla geliştirilmiştir. Ölçekte kitap okumaya yönelik motivasyonu ifade eden 14 madde bulunmaktadır. KOMÖ’nün geçerlik ve güvenirlik çalışmaları kapsamında, yapısal geçerliğini incelemek için Açımlayıcı (AFA) ve Doğrulayıcı Faktör Analizi (DFA) yapılmıştır. Bana Uygun, Bana Biraz Uygun ve Bana Hiç Uygun Değil şeklinde üçlü Likert tipinde düzenlenen ölçek, AFA'ya göre iki faktörlü bir yapıya sahiptir. DFA ile belirlenen modele yönelik uyum katsayıları $[X 2 / d f=2.357$ / RMSEA $=0.047 /$ NNFI=0.946 / CFI=0.954 / GFI=0.958 / AGFI=0.942] olarak belirlenmiştir. Ölçeğin Okuma Sevgisi faktörünün özdeğeri 4.90 ve açıkladığı varyans yüzdesi 35.06, Okuma Sebebi faktörünün özdeğeri 1.57 ve açıkladığı varyans yüzdesi 11.23'tür. Ölçeğin iki faktör yardımıyla açıkladığı toplam varyans ise \%46.29'dur. Ölçeğin Okuma Sevgisi alt boyutunda sekiz, Okuma Sebebi alt boyutunda ise altı madde bulunmaktadır.

Ölçeğin geliştirilme aşamasında hesaplanan Cronbach Alpha güvenirlik katsayıları Okuma Sevgisi alt boyutu için 0,82 , Okuma Sebebi alt boyutu için 0,72 ve ölçek geneli için 0.85 'tir. Ölçeğin bu araştırma kapsamında belirlenen Cronbach Alpha güvenirlik katsayıları ölçek geneli için 0.93, Okuma Sevgisi alt boyutu için 0.88 ve Okuma Sebebi alt boyutu için 0.87 'dir. Ölçeğin alt boyutlarından ve genelinden alınan puanların değerlendirilmesinde kullanılan aralıklar Tablo 1.'de verilmiştir.

Tablo 1. Ölçekten alınan puanların değerlendirilmesinde kullanılan puan aralıkları

\begin{tabular}{lccc}
\hline \multirow{2}{*}{ Boyut } & \multicolumn{3}{c}{ Kitap Okuma } \\
\cline { 2 - 4 } & Düşük & Orta & Yüksek \\
\hline Okuma Sevgisi & $8-13,3$ & $13,4-18,7$ & $18,8-24$ \\
Okuma Sebebi & $6-10$ & $10,1-14$ & $14,1-18$ \\
Ölçek Toplamı & $14-23,3$ & $23,4-32,7$ & $32,8-42$ \\
\hline
\end{tabular}

\section{Verilerin Toplanması ve Analizi}

Veriler ölçeğin her sınıfta araştırmacı tarafından uygulanmasıyla toplanmıştır. Araştırmada veri toplama aracı olarak kullanılan Kitap Okuma Motivasyonu Ölçeği'nin her sınıftaki uygulaması yaklaşık 20 dakika sürmüştür. Verilerin sağlıklı toplanabilmesi için uygulama öncesinde öğrencilere gerekli açıklamalar yapılmış ve ölçeğin nasıl cevaplanacağı bir örnek madde üzerinde öğrencilere anlatılmıştır. Ölçekteki her madde araştırmacı tarafından sırayla sesli olarak okunmuş, daha sonra öğrencilerin okunan maddenin cevabını ellerindeki forma işaretlemeleri sağlanmıştır.

Verilerin analizine geçilmeden önce araştırmaya katılan öğrencilerin KOMÖ’den aldıkları puanların normal dağılım gösterip göstermediği Kolmogorov Smirnov testi ve çarpıklık basıklık değerleri ile incelenmiştir. Yapılan inceleme sonucunda verilerin normal dağılım gösterdiği 
belirlendiğinden istatistikî analizlerde parametrik testler kullanılmıştır. Kitap okuma motivasyonunun cinsiyet ve öğrencilerin kendilerine ait kitaplığa sahip olma durumuna göre farklılık gösterip göstermediği bağımsız gruplar için t-testi ile; anne-baba öğrenim düzeyine göre farklııık gösterip göstermediği ise tek faktörlü ANOVA testi ile incelenmiştir. Araştırmaya katılan Illkokul dördüncü sınıf öğrencilerinin kitap okuma motivasyonlarının Türkçe dersi akademik başarısını ne düzeyde yordadığının belirlenmesi için basit doğrusal regresyon analizi kullanıımıştır. Yapılan tüm analizlerde bilgisayar destekli bir analiz programından yararlanılmıştır.

\section{Bulgular ve Yorum}

Araştırmaya katılan ilkokul dördüncü sınıf öğrencilerinin kitap okuma motivasyonu düzeyleri, öğrencilerin ölçeğin alt boyutlarından ve ölçek genelinden aldıkları toplam puan ortalamaları hesaplanarak incelenmiştir. Yapılan inceleme sonucunda elde edilen bulgular Tablo 2.'de sunulmuştur. Tablo 2. Araştırmaya katılan öğrencilerin kitap okuma motivasyonu düzeyleri

\begin{tabular}{lcccc}
\hline Boyut & $\mathrm{N}$ & $\bar{X}$ & $\mathrm{~S}$ & Motivasyon Düzeyi \\
\hline Okuma Sevgisi & 791 & 16,64 & 4,37 & Orta \\
Okuma Sebebi & 791 & 13,78 & 3,24 & Orta \\
Ölçek Toplamı & 791 & 30,43 & 7,16 & Orta \\
\hline
\end{tabular}

Tablo 2'ye göre araştırmaya katılan öğrencilerin okuma sevgisi, okuma sebebi ve genel kitap okuma motivasyonu düzeyleri "orta" seviyededir. Araştırmaya katılan öğrencilerin kitap okuma motivasyonlarının cinsiyete göre farklılık gösterip göstermediği bağımsız gruplar için t-testi ile incelenmiştir. Yapılan inceleme sonucunda elde edilen sonuçlar Tablo 3'te verilmiştir.

Tablo 3. Kitap okuma motivasyonunun cinsiyete göre t-testi sonuçları

\begin{tabular}{|c|c|c|c|c|c|c|c|}
\hline Boyut & Cinsiyet & $\mathrm{N}$ & $\bar{X}$ & $\mathrm{~S}$ & $\mathrm{Sd}$ & $\mathrm{t}$ & $\mathrm{P}$ \\
\hline \multirow{2}{*}{ Okuma Sevgisi } & $\mathrm{K} I \mathrm{z}$ & 422 & 17,03 & 7,30 & \multirow{2}{*}{789} & \multirow{2}{*}{2,681} & \multirow{2}{*}{,008* } \\
\hline & Erkek & 369 & 16,20 & 6,95 & & & \\
\hline \multirow{2}{*}{ Okuma Sebebi } & Kız & 422 & 13,95 & 4,42 & \multirow{2}{*}{789} & \multirow{2}{*}{1,518} & \multirow{2}{*}{ 129 } \\
\hline & Erkek & 369 & 13,60 & 4,28 & & & \\
\hline \multirow{2}{*}{ Ölçek Toplamı } & $\mathrm{K} ı \mathrm{z}$ & 422 & 30,98 & 3,31 & \multirow{2}{*}{789} & \multirow{2}{*}{2,323} & \multirow{2}{*}{,020* } \\
\hline & Erkek & 369 & 29,80 & 3,17 & & & \\
\hline
\end{tabular}

$*<, 05$

Tablo 3'teki t-testi sonuçlarına göre okuma sevgisi alt boyutu $\left(t_{(2,789)}=2,681 ; p<, 05\right)$ ile genel kitap okuma motivasyonuna $\left(\mathrm{t}_{(2,789)}=2,323 ; \mathrm{p}<, 05\right)$ yönelik olarak cinsiyete göre anlamlı farklılık bulunmaktadır. Grupların ortalama puanları incelendiğinde bu farklılığın kız öğrencilerin lehine olduğu görülmektedir. Okuma sebebi alt boyutunda da kız öğrencilerin ortalama puanının erkek öğrencilerden yüksektir. Ancak bu durum istatistikî olarak anlamlı farklılık oluşturmamaktadır. Elde edilen bulgulara göre kitap okuma motivasyonu bakımından kız öğrencilerin erkek öğrencilerden daha iyi durumda olduğu ifade edilebilir. 
Örneklemde yer alan ilkokul dördüncü sınıf öğrencilerinin kitap okumaya yönelik motivasyonlarının anne-baba öğrenim düzeyine göre anlamlı farklılık gösterip göstermediği KMÖ’nün toplamından alınan puanlara göre incelenmiştir. Yapılan inceleme sonucunda elde edilen betimsel istatistik sonuçları Tablo 4'te sunulmuştur.

Tablo 4. Anne-baba öğrenim düzeyine göre kitap okuma motivasyonu düzeyi

\begin{tabular}{lcccccccc}
\hline Öğrenim Düzeyi & \multicolumn{3}{c}{ Anne } & \multicolumn{1}{c}{ Baba } \\
\cline { 2 - 10 } & $\mathrm{N}$ & $\bar{X}$ & $\mathrm{~S}$ & $\begin{array}{c}\text { Motivasyon } \\
\text { Düzeyi }\end{array}$ & $\mathrm{N}$ & $\bar{X}$ & $\mathrm{~S}$ & $\begin{array}{c}\text { Motivasyon } \\
\text { Düzeyi }\end{array}$ \\
\hline Okur-yazar değil & 15 & 21,33 & 2,09 & Düşük & 10 & 25,90 & 7,85 & Orta \\
Illkokul & 173 & 22,95 & 3,32 & Düşük & 62 & 25,41 & 5,57 & Orta \\
Ortaokul & 213 & 26,01 & 3,11 & Orta & 129 & 27,19 & 6,45 & Orta \\
Lise & 258 & 36,09 & 4,31 & Yüksek & 323 & 29,64 & 6,52 & Orta \\
Üniversite & 132 & 37,33 & 4,06 & Yüksek & 267 & 34,29 & 6,64 & Yüksek \\
\hline
\end{tabular}

Tablo 4'e göre anne öğrenim düzeyi okur-yazar değil ve ilkokul olan öğrencilerin kitap okuma motivasyonu düşük, ortaokul olan öğrencilerin orta ve lise ile üniversite olan öğrencilerin ise yüksek düzeydedir. Bu bulguya göre anne öğrenim düzeyinin öğrencilerin kitap okumaya yönelik motivasyon düzeyi üzerinde etkili olduğu belirtilebilir. Ayrıca baba öğrenim düzeyi üniversite olan grubun kitap okumaya yönelik motivasyon düzeyinin yüksek, diğer grupların iste orta düzeyde olduğu belirlenmiştir. Bu bulguya göre baba öğrenim düzeyi ilkokul olan gruptaki küçük puan düşüşü dikkate alınmazsa, baba öğrenim düzeyinin öğrencilerin kitap okumaya yönelik motivasyon düzeyi üzerinde etkili olduğu söylenebilir.

Araştırmaya katılan öğrencilerin kitap okuma motivasyonlarının anne öğrenim düzeyine göre anlamlı fark gösterip göstermediğine yönelik yapılan tek faktörlü ANOVA sonuçları Tablo 5 'te yer almaktadır.

Tablo 5. Anne öğrenim düzeyine yönelik ANOVA sonuçları

\begin{tabular}{|c|c|c|c|c|c|c|}
\hline Varyansın Kaynağı & Sd & $\begin{array}{l}\text { Kareler } \\
\text { Toplamı }\end{array}$ & $\begin{array}{c}\text { Kareler } \\
\text { Ortalaması }\end{array}$ & $\mathrm{F}$ & $\mathrm{P}$ & Fark \\
\hline Gruplar arası & 4 & 29616,64 & 7404,16 & & & $1-3,1-41-5$ \\
\hline Gruplar içi & 786 & 10959,88 & 13,94 & 530,99 &, $000 *$ & $2-32-42-5$ \\
\hline Toplam & 790 & 40576,52 & & & & $3-43-54-5$ \\
\hline
\end{tabular}

Tablo 5'te yer verilen ANOVA sonuçlarına göre çalışmaya katılan ilkokul dördüncü sınıf öğrencilerinin kitap okumaya yönelik motivasyonları, anne öğrenim düzeyine göre anlamlı farklılık göstermektedir $\left(F_{(4,786)}=530,99 ; p<, 05\right)$. Anlamlı farklılığın hangi gruplar arasında olduğunu belirlemek üzere yapılan Dunnet $C$ testi sonucuna göre anne öğrenim düzeyi okur-yazar değil ve ilkokul olan grupların dışındaki grupların tamamı arasında anlamlı farklılık bulunduğu görülmektedir.

Illkokul dördüncü sınıf öğrencilerinin kitap okuma motivasyonlarının baba öğrenim düzeyine göre anlamlı fark gösterip göstermediğine yönelik yapılan tek faktörlü ANOVA sonuçları Tablo 6'da yer almaktadır. 
Tablo 6. Baba öğrenim düzeyine yönelik ANOVA sonuçları

\begin{tabular}{|c|c|c|c|c|c|c|}
\hline Varyansın Kaynağı & $\mathrm{Sd}$ & $\begin{array}{l}\text { Kareler } \\
\text { Toplamı }\end{array}$ & $\begin{array}{c}\text { Kareler } \\
\text { Ortalaması }\end{array}$ & $\mathrm{F}$ & $P$ & Fark \\
\hline Gruplar arası & 4 & 7302,69 & 1825,67 & \multirow{3}{*}{43,12} & \multirow{3}{*}{,000* } & \multirow{3}{*}{$\begin{array}{l}1-5,2-4,2-5 \\
3-4,3-5,4-5\end{array}$} \\
\hline Gruplar içi & 786 & 33273,83 & 42,33 & & & \\
\hline Toplam & 790 & 40576,52 & & & & \\
\hline
\end{tabular}

Tablo 6'da yer alan ANOVA sonuçlarına göre araştırmaya katılan öğrencilerin kitap okumaya yönelik motivasyonları, baba öğrenim düzeyine göre anlamlı farklılık göstermektedir $\left(F_{(4,786)}=530,99\right.$; $\mathrm{p}<, 05)$. Anlamlı farklılığın hangi gruplar arasında belirlemeye yönelik olarak yapılan Dunnet $\mathrm{C}$ testi sonucunda, baba öğrenim düzeyi üniversite olanlarla okur-yazar değil, ilkokul, ortaokul ve lise olanlar arasında; lise olanlarla ilkokul ve ortaokul olanlar arasında anlamlı farklılık bulunduğu tespit edilmiştir.

Çalışmaya katılan öğrencilerin kitap okumaya yönelik motivasyonlarının kendilerine ait kitaplığa sahip olma durumuna göre anlamlı farklılık gösterip göstermediği bağımsız gruplar için t-testi ile incelenmiştir. Yapılan incelemeye ilişkin t-testi sonuçları Tablo 7'de sunulmuştur.

Tablo 7. Kitap okuma motivasyonunun kitaplığa sahip olma durumuna göre t-testi sonuçları

\begin{tabular}{cllllll}
\hline Kendine Ait Kitaplık & $\mathrm{N}$ & $\overline{\boldsymbol{X}}$ & $\mathrm{S}$ & $\mathrm{Sd}$ & $\mathrm{t}$ & $\mathrm{P}$ \\
\hline Var & 706 & 30,61 & 3,24 & \multirow{2}{*}{789} & 2,040 &, $04^{*}$ \\
Yok & 85 & 28,94 & 3,26 & & & \\
\hline
\end{tabular}

Tablo 7'ye göre kitap okumaya yönelik motivasyonun, kendine ait kitaplığa sahip olma durumuna göre anlamlı farklııık gösterdiği belirlenmiştir $\left(t_{(2,789)}=2,040 ; p<, 05\right)$. Grupların ortalama puanları incelendiğinde farklılığın kendine ait kitaplığa sahip olan öğrencilerin lehine olduğu görülmektedir. Bu bulguya göre öğrencilerin kendine ait kitaplığa sahip olmalarının kitap okumaya yönelik motivasyon üzerinde olumlu etkiye sahip olduğu söylenebilir.

Araştırmaya katılan ilkokul dördüncü sınıf öğrencilerinin kitap okuma motivasyonlarının Türkçe dersi akademik başarısını ne düzeyde yordadığını belirlemek için basit doğrusal regresyon analizi kullanılmıştır. Yapılan analiz sonucunda elde edilen bulgular Tablo 8'de verilmiştir.

Tablo 8. Kitap okuma motivasyonun Türkçe dersi akademik başarısını yordama düzeyi

\begin{tabular}{lrrrrr}
\hline Değişken & B & SH & $\beta$ & t & P \\
\hline Sabit & 3,342 &, 108 & & 30,979 &, 000 \\
Kitap Okuma Motivasyonu & ,031 &, 003 & \multirow{2}{*}{, 301} & 8,871 &, 000 \\
\hline
\end{tabular}

Tablo 8.'de görüldüğü gibi araştırmaya katılan öğrencilerin kitap okuma motivasyonları, öğrencilerin Türkçe dersi akademik başarılarının önemli bir yordayıcısıdır $\left(R=0,301 ; R^{2}=0,091\right.$; 
$\left.F_{(1,789)}=78,697 ; p<0,01\right)$. Elde edilen bulgulara göre Türkçe dersi akademik başarısının \%9'unun kitap okuma motivasyonu ile açıklandığı söylenebilir.

\section{Sonuç, Tartışma ve Öneriler}

Araştırma sonuçlarına göre ilkokul dördüncü sınıf öğrencilerinin kitap okuma motivasyonu düzeyleri orta seviyededir. Okuma motivasyonunun öğrencinin eğitim hayatındaki pek çok şeyi etkilediği göz önüne alındığında motivasyonun okuma ve öğrenme sürecindeki katkısı daha iyi anlaşılabilir. Yıldız ve Akyol'un (2011) yaptığı araştırmaya göre okumaya yönelik içsel motivasyon okuduğunu anlamayı etkilemektedir. Yavaş'ın (2013) yaptığı araştırmada dördüncü ve beşinci sınıf öğrencilerinin kitap okumaya yönelik olumlu inanç ve tutuma sahip oldukları, kitap okuma ve kitaba ulaşma oranlarının yüksek olduğu belirlenmiştir. Bu öğrencilerin sahip oldukları üst düzey düşünme becerilerinin kitap okuma inançları, tutumları ve durumlarıyla olan ilişkisinin yüksek olduğu anlaşılmıştır. Farklı araştırma sonuçları göstermektedir ki motivasyon okumanın farklı bileşenleri üzerinde önemli bir etkiye sahiptir.

Araştırmaya katılan kız öğrencilerin kitap okuma motivasyonlarının erkek öğrencilere göre daha yüksek olduğu belirlenmiştir. Bu sonuç alanyazındaki diğer araştırmaların bulguları ile benzerlik göstermektedir. Yıldız (2010) ve Yıldız (2013) tarafından yapılan araştırmaların sonuçları kızların okumaya yönelik motivasyonlarının erkeklerden daha yüksek olduğunu göstermektedir. Bozkurt ve Memiş'in (2013) beşinci sınıf öğrencileriyle yaptığı araştırmada da kızların okuma motivasyonunun erkeklerden daha yüksek olduğu belirlenmiştir. Marinak ve Gambrel'ın (2010) üçüncü sınıf öğrencileri ile yaptığı araştırmada kız öğrencilerin erkek öğrencilere göre okumaya daha fazla değer verdikleri sonucu ortaya çıkmıştır. Durik, Vida ve Eccles (2006) tarafından dördüncü sınıftan on ikinci sınıfa kadar olan öğrencilerle yürütülen çalışmada kız öğrencilerin okumaya erkek öğrencilerden daha fazla zaman ayırdıkları belirlenmiştir. Güngör'ün (2009) beşinci sınıf öğrencileriyle gerçekleştirdiği çalışmada ise kız öğrencilerin okuma alışkanlıklarının erkek öğrencilerden daha yüksek olduğu anlaşımıştır. Farklı öğrenim düzeylerinde gerçekleştirilen birçok araştırmada da (Arı ve Demir, 2013; Kuş ve Türkyılmaz, 2010; Batur, Gülveren ve Bek, 2010; Bozpolat, 2010; Can, Türkyılmaz ve Karadeniz 2010; Demir, 2009; Odabaş, Odabaş ve Polat, 2008; Gömleksiz, 2004) kadınların okumaya yönelik tutum ya da okuma alışkanlığı bakımından erkeklere göre daha iyi durumda olduğu belirlenmiştir. Alanyazındaki araştırmaların bulguları dikkate alınarak erkeklerin kitap okumaya yönelik tutumlarının ve motivasyonlarının düşük olmasının nedenlerini belirlemeye yönelik araştırmalar yapılabilir.

Araştırmada anne-baba öğrenim durumunun öğrencilerin kitap okuma motivasyonu düzeyi üzerinde etkili olduğu sonucuna ulaşılmıştır. Üniversite ve lise seviyesindeki bir okuldan mezun olan anne ve babaların çocuklarının kitap okuma motivasyonunun diğerlerine göre daha yüksek olduğu anlaşılmıştır. Sever, İnce Samur, Doğan, Çıldır ve Bulut (2013) tarafından ilkokul dördüncü sınıf öğrencileri ile yürütülen çalışmada anne ve baba öğrenim düzeyi yükseldikçe öğrencilerin okuma 
kültürü düzeylerinin de yükseldiği belirlenmiştir. Ülper'in (2011) araştırmasında ilkokul öğrencilerinin çoğu aileyle ilgili etkenlerin kendilerini okumaya güdüleyeceğini belirtmişlerdir. Güngör (2009) tarafından beşinci sınıf öğrencileri ile yürütülen çalışmada ise anne ve babaları üniversite ya da lise mezunu olan öğrencilerin diğerlerine göre daha yüksek düzeyde kitap okuma alışkanlığına sahip oldukları belirlenmiştir. Bu sonuçlar, öğrencilerin kitap okumaya yönlendirilmesinde ailenin sorumluluğuna dikkat çekmektedir. Anne ve babaların, çocuğun okuma alışkanlığı ve motivasyonu üzerindeki rolünün etkisine dayanarak öğretmenlerin anne-babalarla bu konuda işbirliği yapması kaçınılmazdır. Öğretmenler, anne-babalarla öğrencilerin evdeki okuma-yazma alışkanlıkları, ilgileri, hobileri ve birer okuryazar olarak kendileri hakkındaki görüşlerini konuşmak için toplantı yapabilirler. Öğrencilerinin ilgileri hakkında bilgi sahibi olan öğretmenler, kitap seçimi ve anne-babaların evde çocuklarıyla daha fazla okuma-yazma etkinliği yapmalarına yardımcı olabilirler (Tompkins, 2006: 316).

Araştırmaya katılan öğrencilerin \%89'unun kendisine ait bir kitaplığı bulunmaktadır. Ayrıca kendine ait kitaplığı bulunan öğrencilerin, kitaplığı olmayan öğrencilere göre kitap okuma motivasyonunun daha yüksek olduğu belirlenmiştir. Şahin'in (2012) 1384 dördüncü ve beşinci sınıf öğrencisiyle yaptığı araştırmada öğrencilerin \%81'inin kendilerine ait bir kitaplığa sahip oldukları ve sosyo-ekonomik düzey ile öğrencilerin kitaplığa sahip olma durumları arasında anlamlı bir ilişki bulunduğu belirlenmiştir. Bir evde okuma ortamını yaratan, diğer bir deyişle, böyle bir ortamın doğal parçası kitaplıktır. Çocukların, doğdukları andan itibaren sürekli görebilecekleri ve kullanabilecekleri bir kitaplık, çocuk için okuma alışkanlığının ruhsal ve davranışsal etkenlerinden birisi anlamına gelmektedir. Bu nedenle ebeveynlerin, evlerinde bir kitaplık oluşturma sorumluluğu bulunmaktadır (Yılmaz, 2004: 117). Baker'a (2003) göre evdeki okuma çevresi, kitap okuma motivasyonunu artırır ve çocuğun daha istekli okumasına yol açar. Okul-aile işbirliği, okuma motivasyonunun ve okuduğunu anlama becerisinin artırılmasında önemli bir role sahiptir. Okumanın kazandırılması sürecinde en kalıcı ve önemli etken okumanın bir alışkanlık haline dönüştürülmesidir. Okuma alışkanlığı, okumayı kişinin bir ihtiyaç olarak algılaması ve okuma eylemini, hayatının her evresinde sürekli ve düzenli bir şekilde devam ettirmesidir. Okuma alışkanlığı, kişilerin okumayı öğrendikten sonra bu eylemi zevkle yapmalarını sağlamak için kazanmaları gereken önemli bir beceridir (Şahin, 2012: 368). Kitap okuma motivasyonunun artırılmasında ve kitap okuma alışkanlığının kazandııılmasında çocuğun kendine ait bir kitaplığının bulunması ve anne-babanın çocuğa kitap okuma konusunda model olması önemlidir. Bu nedenle velilere yönelik düzenlenecek çalışmalar, öğrencilerin küçük yaşlardan itibaren kitap okuma motivasyonlarının gelişimine katkıda bulunulabilir.

Araştırmada elde edilen sonuçlardan biri de kitap okuma motivasyonunun, Türkçe dersi akademik başarısını yordamada önemli bir değişken olması ve Türkçe dersi akademik başarısının \%9'unu açıklamasıdır. Yıldız (2013) tarafından yapılan araştırmada okuma motivasyonu, akıcı okuma ve okuduğunu anlamanın birlikte akademik başarının \%61'inin açıkladığı tespit edilmiştir. Kitap okuma 
motivasyonun Türkçe dersi ve diğer dersler üzerindeki etkisi daha geniş örneklemler üzerinde gerçekleştirilecek araştırmalarla belirlenebilir.

Edmunds ve Bauserman (2006) tarafından yapılan araştırmaya göre öğrencilerin kitap seçiminde yönlendirici olarak okul kütüphanesi, öğretmenler, aile fertleri ve arkadaşlar olarak sıralanmaktadır. Ayrıca, öğrenciler bir kitabı seçme sebebi olarak öncelikle kitabın özelliklerinin önemli olduğunu; kitabı okumada kendilerini motive eden unsurları aile ve öğretmen olarak ifade etmişlerdir. Ders programlarındaki pek çok konu öğrencinin okul dışındaki yaşamıyla doğrudan ilgilidir. Önemli olan, öğrencilerin bu durumun farkına varabilmesi ve öğrenme heveslerinin artmasıdır. Öğrenmeye yönelik ilgi ve isteğin artırılması için okunacak kitaplarla günlük yaşam arasındaki benzerliklerin ilişkilendirilmesi, kitapların nasıl seçilebileceği, kitapların türleri ve konuları hakkında gerekli açıklamaların düzenli bir şekilde yapılması yararlı olacaktır. Okumayı bir intiyaç ve alışkanlık haline getirilmesi için her zaman göz önünde bulundurması gereken temel ilke, önce öğrencinin okuma eğilimini belirlemek ve onu bu yönde geliştirmektir. Sınıf kitaplığında bulunan kitap ve dergiler öğrencilerin kolaylıkla uzanıp alabilecekleri yerde bulunmalıdır (Ünalan, 2006: 69). Öğrenciler okumak için farklı materyallere sınıf kitaplıklarından ulaşabilirler. Kaliteli kitapların bulunduğu ve kitap seçeneği bakımından zengin olan bir sınıf kitaplığı öğrencilerin bağımsız okuma sürecinde motivasyonlarına olumlu katkı sağlamaktadır (Dreher, 2003: 34).

Öğrencilerin kitap okuma motivasyonlarının artırılması için kütüphanelerin farklı seviye ve tür bakımından zengin kitap hazinesinden yararlanılabilir. Bunun için öğretmenler ile ailelerin çocukları kütüphaneye üyelik konusunda teşvik etmeleri sağlanmalıdır. Okul ve sınıf kütüphaneleri sadece ödev verildiğinde ziyaret edilen mekânlar olmaktan kurtarılarak zengin ve çekici bir öğrenme ortamı olarak tasarlanabilir. Lattanziı JR (2014) tarafından 6. sınıftaki erkek öğrencilerle yapılan araştırmada kitap okuma kulübünün okuma motivasyonu üzerindeki etkisi incelenmiştir. Araştırmada okul dışındaki kitap okuma kulübünde verilen okuma eğitiminin ve okuma paylaşımlarının öğrencilerin kitap okuma isteğini olumlu etkilediği anlaşılmıştır. Ayrıca kitap okuma kulübünün öğrencilerin okuma yaşantısını dönüştürdüğü, okuma stratejilerini bağımsız kullanmaya başlayan öğrencilerin kitap okuma azim ve motivasyonunu artırdığı gözlenmiştir. Bonaria'nın (2011) ilkokul ikinci sınıf öğrencileriyle yaptığı araştırmada kütüphaneden kitap seçme yöntemlerinin okuduğunu anlama ve kitap okuma motivasyonu üzerindeki etkisi incelenmiştir. Araştırma sonuçlarına göre bu yöntemler okuduğunu anlama potansiyelini ve okuma motivasyonunu artırmaktadır. Okullarda yapılan farklı okuma uygulamalarının öğrencilerin kitap okuma motivasyonunu artıracağı düşünülmektedir. Örneğin Thooft (2011) tarafından yapılan araştırma sonucunda sesli kitap kullanımının öğrencilerin okuduğunu anlama ve okuma motivasyonu puanlarını artırdığına ilişkin kanıtlar elde edilmiştir. Ayrıca öğretmenler öğrencilerin okuma isteklerinin artırılmasında sesli kitapların tanıtılması yerine bunların bir okuma programında kullanılmasının daha etkili olacağını belirtmişlerdir. 
Öğrencilerinin kitap okuma isteğini ve motivasyonunu artırmak isteyen öğretmenler farklı okuma etkinlikleriyle bu hedefe katkı sağlayabilirler. Örneğin küçük gruplar halinde aynı kitabı okuma ve kitap üzerinde tartışma; okuma ile ilgili deneyimlerin paylaşıımasını sağlayacak ortamlar oluşturma; her öğrenciye okuduğu kitapla ilgili konuşma fırsatı verme, okunan kitapla ilgili sınıf duvarına asılmak üzere hazırlanan kısa bildiriler hazırlatılması vb. etkinlikler yapılabilir. Okuduğu kitap ile ilgili farklı etkinliklere katılan öğrencilerin kitap okumaya yönelik motivasyonlarının da artacağı düşünülmektedir.

\section{Kaynakça}

Arı, E. ve Demir, M. K. (2013). Illköğretim bölümü öğretmen adaylarının kitap okuma alışkanlıklarının değerlendirilmesi. Ana Dili Eğitimi Dergisi, 1(1), 116-128.

Baker, L. (2003). The role of parents in motivating struggling readers. Reading \& Writing Quarterly: Overcoming Learning Difficulties, 19(1), 87-106. DOI: 10.1080/10573560308207.

Batur, Z., Gülveren, H. ve Bek, H. (2010). Öğretmen adaylarının okuma alışkanlıkları üzerine bir araştırma: Uşak Eğitim Fakültesi örneği. Uşak Üniversitesi Sosyal Bilimler Dergisi, 3(1), 32-49. 06.01.2015 tarihinde sosyaldergi.usak.edu.tr/DergiPdfDetay.aspx?ID=277 adresinden alınmıştır.

Bonaria, A. (2011). A comparison of the effects of library book selection methods on the level of motivation for reading and comprehension skills of second grade students. New Jersey: William Paterson University of New Jersey, Yayımlanmamış Yüksek Lisans Tezi.

Bozkurt, M., Memiş, A.(2013). Beşinci sınıf öğrencilerinin üstbilişsel okuduğunu anlama farkındalı̆ı̆ ve okuma motivasyonları ile okuma düzeyleri arasındaki ilişki. Ahi Evran Üniversitesi Kırşehir Eğitim Fakültesi Dergisi, 14(3), 47-160.

Bozpolat, E. (2010). Öğretmen adaylarının okuma alışkanlı̆̆ına ilişkin tutumlarının değerlendirilmesi (Cumhuriyet Üniversitesi Eğitim Fakültesi örneği). Zeitschrift für die Welt der Türken/Journal of World of Turks, 2(1), 411-428. 05.01.2015 tarihinde http://dieweltdertuerken.org/ index.php/ZfWT/article/viewArticle/116 adresinden alınmıştır.

Can, R., Türkyılmaz, M., Karadeniz, A. (2010). Ergenlik dönemi öğrencilerinin okuma alışkanlıkları. Ahi Evran Üniversitesi Kırşehir Eğitim Fakültesi Dergisi, 11(3), 1-21.

Carnine, D. W., Silbert, J., Kame'enui E. J., Tarver, S. G., Jungjohann K. (2006). Teaching struggling and at-risk readers a direct instruction approach. New Jersey: Pearson Education.

Creswell, J. W. (2014). Araştırma deseni. (Çev. M. Bursal).(ss.155-183). Ankara: Eğiten Kitap.

Demir, T. (2009). Illköğretim II. kademe öğretmen adaylarının okuma alışkanlıkları üzerine bir araştırma (Gazi Üniversitesi örneği). Turkish Studies, 4(3), 717-745. 29.12.2014 tarihinde http://turkishstudies.net/DergiTamDetay.aspx?ID=703\&Detay=Ozet adresinden alınmıştır.

Dreher, M. J. (2003). Motivating struggling readers by tapping the potential of information books. Reading \& Writing Quarterly, 19(1), 25-38. DOI: 10.1080/10573560308206.

Durik, A. M., Vida, M., ve Eccles, J. S. (2006). Task values and ability beliefs as predictors of high school literacy choices: A developmental analysis. Journal of Educational Psychology, 98(2), 382-393. 29.12.2014 
tarihinde http://libra.msra.cn/Publication/36918156/task-values-and-ability-beliefs-as-predictors-ofhigh-school-literacy-choices-a-developmental adresinden alınmıştır.

Edmunds, K. M., Bauserman, K. L. (2006). What teachers can learn about reading motivation through conversations with children. International Reading Association, 414-424. 17.01.2015 tarihinde http://olms.cte.jhu.edu/olms/data adresinden alınmıştır.

Gömleksiz, M. N. (2004). Geleceğin öğretmenlerinin kitap okumaya ilişkin görüşlerinin değerlendirilmesi (Fırat Üniversitesi Eğitim Fakültesi örneği). Yüzüncü Yıl Üniversitesi Elektronik Eğitim Fakültesi Dergisi, 1(1), 121. 19.01.2015 tarihinde http://efdergi.yyu.edu.tr/makaleler/cilt_i/mehmet_nuri.doc adresinden alınmıştır.

Graves, M. F., Juel, C., Graves, B. B., Dewitz, P. (2011). Teaching reading in the 21st century (5. Baskı) Boston: Pearson Education.

Guthrie, J. T. (2011). Best practices in motivating students to read. L. M. Morrow ve L. B.Gambrell (Edt.). Best Practices In Literacy Instruction (pp.177-198) (4.Baskı). NewYork: The Guilford Press.

Guthrie, J. T. (2004). Classroom contexts for engaged reading: An overview. In J. T. Guthrie, A. Wigfield and K. C. Perencevich (Eds). Motivating reading comprehension. Concept-Oriented Reading Instruction (pp. 124). NJ: Lawrence Erlbaum Associates.

Güngör, E. (2009). Ilköğretim 5. sınıf öğrencilerinin kitap okuma alıskanlığı ile Türkçe dersi akademik başarıları arasındaki ilişkinin incelenmesi. Adana: Çukurova Üniversitesi, Yayımlanmamış Yüksek Lisans Tezi.

KatrancI, M. (2015). Book reading motivation scale: Reliability and validity study. Educational Research and Reviews. 10(3), 300-307. doi: 10.5897/ERR2014.1998.

Kuş, Z. ve Türkyılmaz, M. (2010). Sosyal Bilgiler ve Türkçe öğretmeni adaylarının okuma durumları (ilgi, alışanlık ve okuma stratejilerini kullanım düzeyleri). Türk Kütüphaneciliği, 24(1), 11-32.

Kuşdemir, Y. (2014). Doğrudan öğretim modeli'nin ilkokul dördüncü sınıf öğrencilerinin okuduğunu anlama becerilerine etkisi. Ankara: Gazi Üniversitesi, Yayımlanmamış Doktora Tezi.

Lattanzi JR., J. A. (2014). Just don't call it a book club: Boys' reading experiences and motivation in school and in an after school book club. New Jersey: The State University of New Jersey, Yayımlanmamış Doktora Tezi.

Marinak, B. A. ve Gambrell, L. B. (2010). Reading motivation: Exploring the elementary gender gap. Literacy Research and Instruction, 49(2), 129-141. DOI: 10.1080/19388070902803795.

Odabaş, H., Odabaş, Y., ve Polat, C. (2008). Üniversite öğrencilerinin okuma alışkanlığı: Ankara Üniversitesi örneği. Bilgi Dünyası, 9(2), 431-465. 19.02.2015 tarihinde http://eprints.rclis.org/12704/ adresinden alınmıştır.

Sedat, A., İnce Samur, A., Doğan, B. N., Çıldır, B., Bulut, S. (2013). Illkokul 4. sınıf öğrencilerinin okuma kültürü edinme düzeyleri ile kitle iletişim araçlarını kullanma alışkanlıklarının incelenmesi. I. Türkiye Çocuk ve Medya Kongresi Bildiri Kitabı, I. Cilt, 371-395.

Selçuk, Z. (2007). Eğitim psikolojisi. Ankara: Nobel Yayın Dağıtım.

Slavin, R. E. (2013). Eğitim psikolojisi. (10. Baskı) (Çev. Edt. G. Yüksel). Ankara: Nobel Yayın Dağııım. 
Şahin, A. (2012). İlköğretim 4 ve 5. sınıf öğrencilerinin kitap okuma alışkanlıklarının sosyo-ekonomik düzeylerine göre incelenmesi. Türk Eğitim Bilimleri Dergisi, 10(2), 367-388.

Thooft, N. A. (2011). The effect of audio books on reading comprehension and motivation. A Master's Project Report. College of St. Scholastica.

Tompkins, G. E. (2006). Literacy fort the 21st centruy a balanced. (Fourt Edition). New Jersey: Pearson.

Ülper, H. (2011). Öğrenci açısından okumaya güdüleyici etmenler. Kuram ve Uygulamada Eğitim Bilimleri, 11(2), 941-960. 11.12.2014 tarihinde http://www.edam.com.tr/kuyeb/tr/makale.asp?ID=521\&act=detay adresinden alınmıştır.

Ünalan, Ş. (2006). Türkçe öğretimi. (3. Baskı). Ankara: Nobel.

Yavaş, S. (2013). Ilköğretim 4. ve 5. sınıf öğrencilerinin kitap okuma alışkanlıkları ile üst düzey düşünme becerileri arasındaki ilişkinin değerlendirilmesi. Konya: Necmettin Erbakan Üniversitesi, Yayımlanmamış Yüksek Lisans Tezi.

Yıldız, M., Akyol, H. (2011). İlköğretim 5. sınıf öğrencilerinin okuduğunu anlama, okuma motivasyonu ve okuma alışkanlıkları arasındaki ilişki. Gazi Eğitim Fakültesi Dergisi, 31(3), 793-815.

Yıldız, M. (2013). İlköğretim 3, 4 ve 5. sınıf öğrencilerinin okuma motivasyonlarının incelenmesi. Eğitim ve Bilim, 38(168), 260-271.

Yıldız, M. (2010). ilköğretim 5. sınıf öğrencilerinin okuduğunu anlama, okuma motivasyonu ve okuma alışkanlığı arasındaki ilişki. Ankara: Gazi Üniversitesi, Yayımlanmamış Doktora Tezi.

Yılmaz, B. (2004). Öğrencilerin okuma ve kütüphane kullanma alışkanlıklarında ebeveynlerin duyarlılığı. Bilgi Dünyası, 5(2), 115-136. 25.02.2015 tarihinde http://eprints.rclis.org/7362/1/ 115-136.pdf adresinden alınmıştır. 